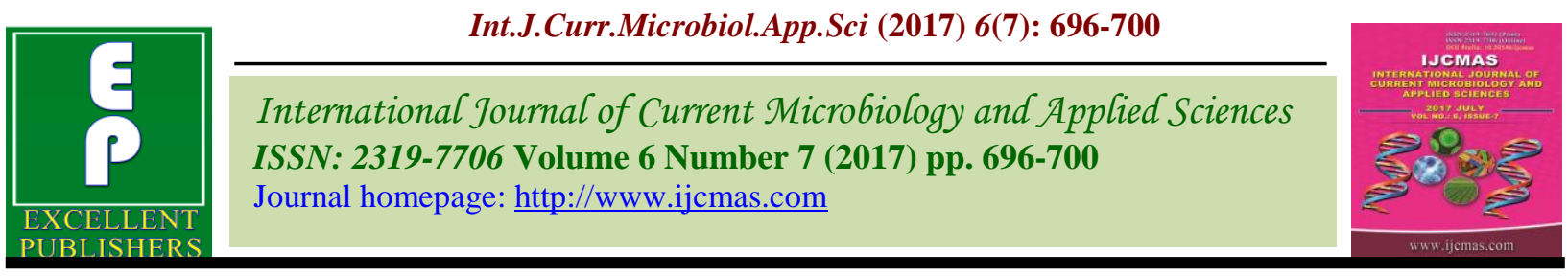

Original Research Article

https://doi.org/10.20546/ijcmas.2017.607.086

\title{
Quality of Ginger (Zingiber officinale Rosc.) Genotypes under Shade Net Condition of Costal Andhra Pradesh
}

\author{
M. Surendra Babu*, B. Prasanna Kumar, D.V. Swami, K. Uma Krishna and N. Emmanuel \\ Horticultural College and Research Institute, Y.S.R H.U, Venkataramannagudem, \\ West Godavri (d.t) Andhra Pradesh, 534101, India \\ *Corresponding author
}

\begin{tabular}{|c|c|}
\hline & A B S T R A C T \\
\hline & \multirow{7}{*}{$\begin{array}{l}\text { A field experiment on ginger (Zingiber officinale Rosc.) was conducted at College of } \\
\text { Horticulture Dr. Y.S.R Horticultural University, Andhra Pradesh during 2014-2016 to } \\
\text { study the yield and quality performance of ten varieties of ginger. Among the varieties, } \\
\text { Suprabha recorded the highest rhizome yield }\left(32.02 \mathrm{t} \mathrm{ha}^{-1}\right) \text {, specific gravity }\left(1.27 \mathrm{~g} \mathrm{~cm}^{-3}\right) \\
\text { and dry recovery }(22.00 \%) \text { where as the variety Regodi has recorded highest oleoresin } \\
(10.10 \%) \text {. Himachal recorded significantly higher essential oil }(2.95 \%) \text {, Zaherabad local } \\
\text { recorded higher peel } / 100 \mathrm{~g} \text { of rhizome }(18.40 \mathrm{~g}) \text {, and peel and pulp ratio }(0.22) \text { and } \\
\text { Pundibari had recorded higher pulp/100 g of rhizome }(89.80 \mathrm{~g}) \text {. There is a need for } \\
\text { genetically superior strains contain high essential oil and oleoresin content. Besides obtain } \\
\text { higher yields, superior quality of the produce is also important for export to fetch premium } \\
\text { price in the international market. Quality of the produce is largely determined by the } \\
\text { minimum fiber content and good aroma. On the basis of good performance with oleoresin } \\
\text { content, the genotype Regodi may be considered as the most suitable for quality aspects. }\end{array}$} \\
\hline & \\
\hline $\begin{array}{l}\text { Genotypes, } \\
\text { Ouality, Yield }\end{array}$ & \\
\hline $\begin{array}{l}\text { Quality, Y1eld, } \\
\text { Zingiber officinale }\end{array}$ & \\
\hline Rosc. & \\
\hline Article Info & \\
\hline $\begin{array}{l}\text { Accepted: } \\
\text { 14 June } 2017 \\
\text { Available Online: } \\
10 \text { July } 2017\end{array}$ & \\
\hline
\end{tabular}

\section{Introduction}

Ginger (Zingiber officinale Rosc.) is one of the major spices cultivated in India. India is the world's largest producer and exporter of ginger. Quality of ginger is mainly determined by its essential oil, oleoresin, peel and pulp quantity. Ginger is mainly grown in India, China, Jamaica, Taiwan, Sierra Leone, Nigeria, Fiji, Mauritius, Indonesia, Brazil, Costa Rica, Ghana, Japan and Thailand, an annual production of 6.55 lakh tones in an area of about 1.33 lakh hectares in India, contributing approximately 65 per cent of the world production. Ginger production share among the spices in India is 11.89 per cent, Spices take up 13 per cent of the area under cultivation (NHB Database 2014-15). Ginger is grown as an intercrop in coconut and arecanut plantations in the states of Kerala, Meghalaya, Orissa and West Bengal and to some extent in Karnataka as well as pure crop in states of Andhra Pradesh and Tamil Nadu. Its cultivation is fast increasing as a pure crop particularly in these states because of better profitability and high productivity can be expected by providing favourable conditions and better management (Vastrad et al., 2006). There is a need for genetically superior strains containg in high essential oil, oleoresin content. The productivity of ginger varies among the different cultivars grown under different agro climatic conditions. The quality parameters like essential oil and oleoresin 
content, specific gravity, peel per 100 gram of ginger $(\mathrm{g})$, pulp per 100 gram of ginger $(\mathrm{g})$ and peel and pulp ratio and recovery of dry ginger $(\%)$ are the important qualitative characters which are influenced by variety and climatic conditions. The quality of ginger is also an important factor for export which varies from variety to variety grown under different situations. In the present investigation an attempt has been made to find out the performance of different varieties under local agro climatic zone for their suitability and also to mitigate adverse condition through shade net cultivation and to find out a suitable variety by its performance under shade net condition for the coastal region of Andhra Pradesh.

\section{Materials and Methods}

The experiment was carried out during kharif, 2015-2016 at Horticultural College, Dr.Y.S.R. Horticultural University, Venkataramannagudem, West Godavari district, Andhra Pradesh. The location falls under agro-climatic zone of humid, east coast plain and hills (Krishna and Godavari zone) with an average rainfall of $900 \mathrm{~mm}$. The experimental area lies under sub tropical climate. The maximum temperature ranged between $29.25^{\circ} \mathrm{C}$ and $42.63^{\circ} \mathrm{C}$, relative humidity varied from a minimum of 31.79 to 78.53 per cent which is characterized by heavy rainfall $(260.08 \mathrm{~mm})$ during the months of June to October and scanty during rest of the year.

A total of 87.60 per cent of annual rainfall was received through south west monsoon and the remaining through North East monsoon. The trail was conducted in red sandy loam soils under shade net house. It is covered with green colour plastic net, and it allows 50 per cent light. It provides partially controlled atmosphere by reducing light intensity and temperature during day time to the crops grown under it. The experimental field was thoroughly ploughed with power tiller to a depth of $30 \mathrm{~cm}$ and harrowed twice to a fine tilth. The field was leveled and divided into plots of raised beds as per the layout of the experiment. Each replication was represented by 10 rows and 3 columns of $2.0 \mathrm{~m}$ length, $2.0 \mathrm{~m}$ breadth and the spacing was $35 \mathrm{~cm}$ between the rows and $25 \mathrm{~cm}$ between the plants. The numbers of plants per plot of 4 sq $m$ were 42 .

The ten treatments replicated thrice in randomized block design in first week of June, healthy rhizome bits (25-30 g) were planted in plots of $2 \times 2 \mathrm{~m}$ size at a spacing of $35 \times 25 \mathrm{~cm}$. Prior to planting well rotten farmyard manure $\left(25 \mathrm{t} \mathrm{ha}^{-1}\right)$ was applied. Weeding, irrigation and plant protection were carried out as required quantity. The specific gravity of the rhizome was assessed by water displacement method as followed by Chopra (2001). Oleoresin in ginger was extracted in a Soxhlet's apparatus by using solvent acetone (Anonymous, 1984).

\section{Procedure}

Ginger rhizomes harvested at 180 days stage were dried in a hot air oven at $50^{\circ} \mathrm{C}$ and powdered finely in a mixer grinder. Two grams of ginger powder was weighed and packed in filter paper and placed in Soxhlet's apparatus. $200 \mathrm{ml}$ of acetone was taken in the round bottom flask of the apparatus and heated in a mantle.

The temperature was maintained at the boiling point of the solvent (around $60^{\circ} \mathrm{C}$ ). After complete extraction (4-5 hours) the solvent was evaporated to dryness.

Yield of oleoresin on dry weight basis was calculated using the formula.

$$
\text { Oleoresin }(\%)=\frac{\text { Weight of oleoresin }}{\text { Weight of sample }} \times 100
$$




\section{Essential oil}

Essential oil content on fresh weight basis was determined by steam distillation of freshly harvested rhizomes using Clevenger apparatus. Fresh rhizomes were boiled for about 8 to 10 hours in the Clevenger apparatus and oil content was recorded.

\section{Results and Discussion}

The fresh rhizome yield and quality attributes recorded in 10 ginger genotypes is presented in Table-1 and 2. Among the ginger genotypes the variety Suprabha recorded highest specific gravity $\left(1.27 \mathrm{~g} \mathrm{~cm}^{-3}\right)$ followed by Himachal $\left(1.25 \mathrm{~g} \mathrm{~cm}^{-3}\right)$, Mahima $\left(1.23 \mathrm{~g} \mathrm{~cm}^{-3}\right)$, Zaherabad Local $\left(1.23 \mathrm{~g} \mathrm{~cm}^{-3}\right)$ and Regodi $\left(1.22 \mathrm{~g} \mathrm{~cm}^{-3}\right)$ which was on par with each other and the variety Pundibari had recorded lowest specific gravity $\left(1.18 \mathrm{~g} \mathrm{~cm}^{-3}\right)$. As the dry matter is positively correlated with specific gravity on represented by Jyotsna et al., (2012).

The highest peel per $100 \mathrm{~g}$ of rhizome was recorded by the variety Zaherabad local $(18.40 \mathrm{~g})$ followed by Mahima $(16.64 \mathrm{~g})$ and Maran (16.53g) which was on par with each other. The lowest peel per $100 \mathrm{~g}$ of rhizome was recorded in the variety Pundibari (10.20 $\mathrm{g}$ ). The pulp per $100 \mathrm{~g}$ of rhizome showed the significant differences among the varieties and the highest pulp per $100 \mathrm{~g}$ of rhizome (89.80 g) was recorded by Pundibari followed by Regodi (89.60 g), Jalsingapara Local $(88.60 \mathrm{~g})$ and Nadia $(87.90 \mathrm{~g})$ which was on par with each other.

The lowest pulp per $100 \mathrm{~g}$ of rhizome was recorded in the variety Zaherabad local $(81.60$ g). The peel and pulp ratio of rhizome showed the significant differences among the varieties. The higher peel and pulp ratio of rhizome were recorded in the variety Zaherabad Local (0.22) followed by Mahima
(0.20) and Maran (0.19) which was on par with each other and the lowest peel and pulp ratio of rhizome was recorded in the varieties Regodi and Pundibari (0.11). It might be attributed to genetical character of the variety which is exhibited under low light intensity under shade net condition.

The highest fresh rhizome yield per hectare was recorded in the variety Suprabha (32.02 t $\mathrm{ha}^{-1}$ ) followed by Himachal $\left(30.53 \mathrm{tha}^{-1}\right)$ and the lowest fresh rhizome yield per hectare was recorded by Nadia $\left(20.47 \mathrm{t} \mathrm{ha}^{-1}\right)$.

The highest fresh rhizome yield produced by some of these varieties can be mainly attributed to vegetative growth characters like plant height, number of leaves, leaf area per plant, the fresh weight of rhizomes, length of rhizome and girth of rhizome under shade net condition. It can be attributed that the yield of a variety is dependent on vigour of the plant and other rhizome characters (Sanwal et al., 2012; Chongtham et al., 2013; Raviraja Shetty et al., 2015).

The oleoresin content showed significant differences among the varieties and the highest oleoresin content of $10.10 \%$ was recorded in Regodi followed by varieties Himachal (9.00 \%) and Zaherabad Local $(9.00 \%)$ whereas, the lowest oleoresin content was recorded in the variety Jalsingapara Local $(6.20 \%)$. It might be due to variations in maturity, genotype and agro climatic condition in the shade net.

Similar results were reported by Kale (2001), Iwo et al., (2011), Kale et al., (2003) and Nileena et al., (2014) in ginger. The data for the character higher essential oil content was recorded in the variety Himachal $(2.95 \%)$ which was followed by variety Maran (2.80 $\%)$ and the lowest was found in Narsipatnam Local $(2.15 \%)$. 
Table.1 Performance of different varieties of ginger rhizomes for specific gravity $(\mathrm{g} / \mathrm{cm} 3)$, peel / 100 gram of rhizome $(\mathrm{g})$, pulp/ 100 gram of rhizome $(\mathrm{g})$ and peel/pulp ratio under shade net condition

\section{Quality parameter}

\begin{tabular}{|l|c|c|c|c|}
\hline Treatments & $\begin{array}{c}\text { Specific gravity } \\
\left(\mathbf{g} / \mathbf{c m}^{\mathbf{3}}\right)\end{array}$ & $\begin{array}{c}\text { Peel / 100 gram of } \\
\text { rhizome }(\mathbf{g})\end{array}$ & $\begin{array}{c}\text { Pulp/ 100 gram of } \\
\text { ginger }(\mathbf{g})\end{array}$ & Peel/pulp ratio \\
\hline $\mathrm{V}_{1}$-Maran & 1.20 & 16.53 & 83.46 & 0.19 \\
\hline $\mathrm{V}_{2}$-Mahima & 1.23 & 16.64 & 83.36 & 0.20 \\
\hline $\mathrm{V}_{3}$-Regodi & 1.22 & 10.40 & 89.60 & 0.11 \\
\hline $\mathrm{V}_{4}$-Zahearabad local & 1.23 & 18.40 & 81.60 & 0.22 \\
\hline $\mathrm{V}_{5}$-Suprabha & 1.27 & 13.40 & 86.60 & 0.15 \\
\hline $\mathrm{V}_{6}$-Nadia & 1.21 & 12.10 & 87.90 & 0.13 \\
\hline $\mathrm{V}_{7}$-Pundibari & 1.18 & 10.20 & 89.80 & 0.11 \\
\hline$V_{8}$-Jalsingapara local & 1.19 & 11.40 & 88.60 & 0.13 \\
\hline $\mathrm{V}_{9}$-Himachal & 1.25 & 13.20 & 86.80 & 0.15 \\
\hline $\mathrm{V}_{10}$-Narsipatnam local & 1.19 & 13.10 & 86.96 & 0.15 \\
\hline SE (m) \pm & $\mathbf{0 . 0 1}$ & $\mathbf{0 . 7 2}$ & $\mathbf{0 . 7 8}$ & $\mathbf{0 . 0 1}$ \\
\hline CD at 5\% & $\mathbf{0 . 0 5}$ & $\mathbf{2 . 1 7}$ & $\mathbf{2 . 3 5}$ & $\mathbf{0 . 0 3}$ \\
\hline CV\% & $\mathbf{2 . 4 5}$ & $\mathbf{9 . 2 8}$ & $\mathbf{1 . 5 7}$ & $\mathbf{1 1 . 5 8}$ \\
\hline
\end{tabular}

Table.2 Performance of different ginger (Zingiber officinale Rosc.) varieties for oleoresin (\%), essential oil (\%) and recovery of dry ginger (\%) under shade net condition

\begin{tabular}{|l|l|l|l|l|}
\hline Treatments & $\begin{array}{l}\text { Fresh rhizome } \\
\text { yield/ ha }(\mathbf{t})\end{array}$ & Oleoresin $(\%)$ & Essential oil $(\%)$ & $\begin{array}{l}\text { Recovery of dry } \\
\text { ginger }(\boldsymbol{\%})\end{array}$ \\
\hline $\mathrm{V}_{1}$-Maran & 22.36 & $7.50(15.88)$ & $2.80(9.63)$ & $19.50(26.2)$ \\
\hline $\mathrm{V}_{2}$-Mahima & 24.36 & $6.80(15.11)$ & $2.60(9.28)$ & $19.10(25.90)$ \\
\hline $\mathrm{V}_{3}$-Regodi & 25.62 & $10.10(18.52)$ & $2.35(8.81)$ & $19.00(25.82)$ \\
\hline $\mathrm{V}_{4}$-Zahearabad local & 26.25 & $9.00(17.45)$ & $2.50(9.09)$ & $20.50(26.91)$ \\
\hline $\mathrm{V}_{5}$-Suprabha & 32.02 & $8.60(17.05)$ & $2.35(8.81)$ & $22.00(27.97)$ \\
\hline $\mathrm{V}_{6}$-Nadia & 20.47 & $6.40(14.65)$ & $2.15(8.43)$ & $18.40(25.39)$ \\
\hline $\mathrm{V}_{7}$-Pundibari & 29.92 & $8.40(16.84)$ & $2.45(9.00)$ & $19.80(26.41)$ \\
\hline $\mathrm{V}_{8}$-Jalsingapara local & 27.61 & $6.20(14.41)$ & $2.30(8.72)$ & $19.23(25.99)$ \\
\hline $\mathrm{V}_{9}$-Himachal & 30.53 & $9.00(17.45)$ & $2.95(9.89)$ & $19.60(26.27)$ \\
\hline $\mathrm{V}_{10}$-Narsipatnam local & 23.20 & $8.50(16.95)$ & $2.15(8.43)$ & $17.60(24.78)$ \\
\hline SE (m) \pm & $\mathbf{0 . 5 1}$ & $\mathbf{0 . 2 8}$ & $\mathbf{0 . 0 7}$ & $\mathbf{0 . 8 1}$ \\
\hline CD at 5\% & $\mathbf{1 . 5 3}$ & $\mathbf{0 . 8 4}$ & $\mathbf{0 . 2 1}$ & $\mathbf{N S}$ \\
\hline CV $(\boldsymbol{\%})$ & $\mathbf{3 . 3 9}$ & $\mathbf{6 . 0 7}$ & $\mathbf{4 . 9 4}$ & $\mathbf{7 . 2 3}$ \\
\hline
\end{tabular}

Note: Values in the parenthesis arc o sin transformed values.

The presence of essential oil in the outer skin established by histo chemical examination of ginger peel confirms decreasing levels of essential oil during rhizome development. This might have resulted in the negative correlation of the oleoresin with yield. The genotypes with lowest yield but high essential oil contents were recorded in Himachal. The difference in quality parameters might be due to the inherent characters of the each variety. Similar results were observed by Kanjilal et al., (1997), Rajni Bala et al., (2007) and Sanwal et al., (2012) in 
ginger. The recovery of dry ginger content was showed non-significant among different varieties however, the variety Suprabha recorded the highest recovery of dry ginger $(22.00 \%)$ and the lowest recovery of dry ginger was recorded by Narsipatnam local $(17.60 \%)$. In conclusion, with the present investigation it can be concluded that, the genotypes exhibited differences with respect to yield and quality parameters. Among ten cultivars Suprabha, Regodi, Himachal, Zaherabad local and Pundibari, performed well with respect to yield and quality characters. Significant variations were observed in terms of yield and quality under shade net condition, these five cultivars were suitable for commercial production of ginger under shade net condition of costal Andhra Pradesh.

\section{References}

Anonymous. 1984. Official Methods of Analysis. Association of Official Analytical Chemists, $14^{\text {th }}$ Edition, Washington, pp.153

Chongtham,T., Chatterjee, R., Hnamte, V., Chattopadhyay, P.K. and Khan, S.A. 2013. Ginger (Zingiber officinale Rosc.) germplasm evaluation for yield and quality in southern West Bengal, J. Spices and Aromatic Crops, 22(1): 88-90.

Chopra, C.S. 2001. Practical manual of fruit and veg analysis. Dep. food science and technology, ND University of Agricultural and Technology, Kumarganj, Faizabad, Uttar Pradesh, India.

Iwo, G.A., Uwah, D.F and Uko, A.E. 2011. Variation in agronomic performance and proximate composition of some ginger genotypes in the humid agro-ecology of Nigeria. J. Agri. Biotechnol. Ecol., 4(1): 1318.

Jyotsna, N., Ghosh, D.C and Meitei, W.I. 2012. Study of growth, yield and quality of organically grown ginger varieties under rain fed condition of Manipur. J. Crop and Weed, 8(1): 17-21.

Kale, U.B. 2001. Evaluation of ginger (Zingiber officinale Rosc.) genotypes under Ghataprabha Left Bank Command area of northern Karnataka. M.Sc. (Hort.) Thesis, University of Agricultural Sciences, Dharwad.

Kale, U.B. Hedgde, N.K. Hanamashetti, S.I. and Patil, P.L. 2003. Quality of ginger genotypes under Ghataprabha left bank command area of northern Karnataka. Karnataka J. Agric. Sci., 16(4): 633-635.

Kanjilal, P.B., Sarma, M.N., Siddique, I.H., Kotoky, R., Pthak, M.G and Singh, R.S. 1997. Yield and quality of ginger (Zingiber officinale Rosc.) grown in Nagaland, India. J. Spices and Aromatic Crops, 6(1): 43-47.

NHB. 2014. Indian Horticulture Database-2014. National Horticulture Board, Gurgon, Govt. of India.www.nhb.gov.in.

Nileena, C.R., Srinivasan, V., Hamza, S., Leela, N.K and Thankamani, C.K. 2014. Quality profile of ginger under different management systems. J. Spices and Aromatic Crops, 23(1): 125-129.

Rajani Bala, Korla, B.N. and Neerja Rana. 2007. Evaluation of ginger clones for quality attributes for Himachal Pradesh. Haryana J. Hortic. Sci., 36(1\&2): 198-199.

Raviraja Shetty, G., Kallappa Narode and Venkatesha. J. 2015. Performance of ginger (Zingiber officinale Rosc.) varieties under hill zone of Karnataka. Environ. and Ecol., 33(3): 1196-2000.

Sanwal, S.K., Singh, S.K., Yadav, R.K., Singh. P.K and Misra. A.K. 2012. Yield and quality assessment of ginger (Zingiber officinale Rosc.) genotypes. Indian J. plant Genet. Resour., 25(3): 281-286.

Vastrad, N.V. 2006. Effect of light intensity and vaermicompost an yield of ginger. Karnataka J. Agric. Sci., 19(4): 941-945.

\section{How to cite this article:}

Surendra Babu, M., B. Prasanna Kumar, D.V. Swami, K. Uma Krishna and Emmanuel, N. 2017. Quality of Ginger (Zingiber officinale Rosc.) Genotypes under Shade Net Condition of Costal Andhra Pradesh. Int.J.Curr.Microbiol.App.Sci. 6(7): 696-700.

doi: https://doi.org/10.20546/ijcmas.2017.607.086 